\title{
Integration of Cattle Production and Marketing Strategies with Improved Pastures and Native Range
}

\author{
D.E. ETHRIDGE, J.D. NANCE, AND B.E. DAHL
}

\begin{abstract}
Forty-eight stocker cattle enterprises on tobosagrass, bluestem, and lovegrass pastures being bought and sold at different points in the seasonal cattle price cycle were evaluated to determine the set of enterprises which maximize ranch profits. All optimal plans for the 397-ha $(980 \mathrm{ac})$ ranch included enterprises which showed ranch profit gains from forfeiture of some physical weight gains for the price advantages of off-season buying/selling.
\end{abstract}

Key words: cattle production and marketing, seasonal grass management, ranch management, linear programming

While net returns to ranching have been declining in recent years, rates of return on investment in ranching have historically been low. U.S. agricultural production costs rose at an annual rate of $9.6 \%$ between 1978 and 1982 (U.S. Dept. of Agr. 1984) while cattle prices rose at an annual rate of $4.9 \%$ in the same period (Tex. Crop and Livestock Reporting Serv. 1984). However, the 25\% increase in cattle prices over the 4-year period was not uniform across months. For example, April cattle prices increased at an 8.6\% annual rate while October prices increased at a $1.4 \%$ annual rate. Most producers purchase cattle or produce spring calves when native range grasses become most productive and cattle prices are highest, and sell in October or November when grasses become dormant and cattle prices are lowest. While this strategy is efficient for weight gains, it may not be economically efficient.

A profitable alternative may be available when high producing grasses such as weeping lovegrass (Eragrostis curvula) and old world bluestem (Bothriochloa ischaemum var. ischaemum) are established on a portion of ranch acreage, altering the production period and exploiting the seasonal cattle price pattern. The objectives of this study were to identify feasible alternative purchase and sale dates for stocker cattle enterprises on lovegrass, bluestem, and tobosagrass pastures in the Southern High Plains/Rolling Plains and determine the combinations of enterprises which maximize profits for ranches in the region. Objectives did not include determination of optimum acreages of the various pastures, but annualized establishment costs for improved pastures were included in enterprise costs. The optimum combinations of enterprises were evaluated on a model ranch which has the improved pastures established.

Several studies with related emphases have been done. Angirasa et al. (1981) evaluated a related question of fall and spring calving in East Texas. Leistritz and Qualey (1975) analyzed use of various forages and alternative sale dates of calves in a cow-calf operation in southwestern North Dakota. Lance et al. (1974) studied the profitability of winter and summer stocker and cow-calf enterprises for the southeastern U.S. and concluded that a combination of summer cow-calf and winter stockers was the optimal production system. Woodworth (1973) determined the optimal distribution of steers and heifers between 2 types of pastures. Kennedy (1972) described a method to determine optimal production possibilities for stocker enterprises which included using capital budgets for a wide range of management practices. That approach was used

\footnotetext{
The authors are professor and former research assistant, Agricultural Economics Department, and professor, Range and Wildlife Management Department, Texas Tech University, Lubbock 79409.

Texas Tech University College of Agricultural Sciences Publication No. T-1-236.

The authors wish to thank R.P. Kennedy, R.T. Ervin, R.E. Sosebee, R.H. Hart, and two anonymous reviewers for their comments and suggestions.

Manuscript accepted 8 December 1986.
}

in this study. Bentley and Shumway (1981) showed that forecasts of patterns in beef prices could be incorporated in profit maximizing ranch management decisions.

\section{Methods}

The Texas Tech Experimental Ranch, located at Justiceburg, Texas, in the eastern part of Garza county, has $397 \mathrm{ha}(980 \mathrm{ac})$ of productive land, consisting of pastures of weeping lovegrass, old world bluestem, and native tobosagrass (Hilaria mutica). It was used as the model ranch for this analysis. The bluestem and lovegrass pastures each contain $30 \mathrm{ha}(75 \mathrm{ac})$. The tobosagrass area, 336 ha $(830 \mathrm{ac})$, was treated with herbicides in 1983 for honey mesquite (Prosopis glandulosa), was burned in 1981, 1982, and $1983(1 / 3$ each year), and has about $10 \%$ canopy cover. All 3 pastures have rotation grazing systems using 6 paddocks in each pasture. The herd on tobosagrass is rotated weekly while the herds on lovegrass and bluestem are rotated by decision as dictated by pasture conditions. The estimated annual grass production available for grazing, based on clipping samples from these and other sites, was 3,226 $\mathrm{kg} / \mathrm{ha}(2,880 \mathrm{lb} / \mathrm{ac})$ for the bluestem, $3,584 \mathrm{~kg} / \mathrm{ha}(3,200 \mathrm{lb} / \mathrm{ac})$ for the lovegrass, and $806 \mathrm{~kg} / \mathrm{ha}(720 \mathrm{lb} / \mathrm{ac})$ for the tobosagrass. Fertilized bluestem commonly yields 4,000 to $4,500 \mathrm{~kg} / \mathrm{ha}$ in the area. Similarly, lovegrass yields from 4,500 to $5,000 \mathrm{~kg} /$ ha and unfertilized tobosagrass 1,300 to $1,600 \mathrm{~kg} / \mathrm{ha}$. These values assume that at least $900 \mathrm{~kg} / \mathrm{ha}(800 \mathrm{lb} / \mathrm{ac})$ will be left on bluestem and lovegrass pastures and that $540 \mathrm{~kg} / \mathrm{ha}(480 \mathrm{lb} / \mathrm{ac})$ will be left on tobosagrass pastures to allow for maintenance of stand. The production estimate for the tobosagrass site is conditioned on prescribed burning on a cycle of approximately 5 years.

The enterprises examined consisted of stocker steers and stocker heifers. The enterprises differed in the purchase weights, purchase and sale dates of the cattle, and in types of forage consumed. Alternative purchase and sale dates were selected from 566 enterprises (Nance et al. 1985) on the basis of profitability of the enterprise, affected by rate of weight gain and price spreads between purchase and sale, and technical feasibility, affected by forage availability in different months. Weight gains for each enterprise were based on unpublished experimental data and experience from operating the ranch. Considerable data compare steers and heifers before weaning and in the feedlot phases of cattle production, but little data exist for the stocker pasture and range phase. However, from the relatively few pasture studies conducted with stockers, little difference exists between weight gains of steers and heifers for this phase. The only published comparative data found confirmed this and was from Kessler et al. (1951) in a Kansas study. Also Snapp (1949) and Morrison (1949) report from several Midwestern feedlot studies that if steers and heifers are marketed when the finish required for the respective sex is attained, heifers gained as well or better than steers. However, when both sexes were fed the same length of time the steers outperformed the heifers. For lack of a better guide, this analysis assumed the same daily gain from steers and heifers. There are, however, differences in rate of weight gain from both steers and heifers in different months; cattle on pasture gain more rapidly during the spring, summer, and fall periods than during the winter months even with supplemental feeding in the winter.

Enterprise budgets constructed for each alternative strategy and 
procedure are described in Nance et al. (1985). The budgets were also modified to determine costs and returns for alternative levels of cattle prices.

A linear programming model was constructed to determine the combination of enterprises for maximum net revenue with high, low, and average cattle prices. Profitability for each enterprise was indicated by its residual returns to land and management.

Seven stocker steer and ten stocker heifer enterprises on bluestem were evaluated in the model (Table 1). Two heifer enterprises, CB1 and CB2, were purchased October 15 and grazed initially on tobosagrass, then rotated to bluestem on June 1 and 15 , where they remained until sold. Seven stocker steer and ten stocker heifer enterprises were considered for the lovegrass. Three heifer enterprises, CL1-CL3, were grazed on tobosagrass from their purchase date until May 15, June 1, and June 15, respectively, then rotated to lovegrass for the duration of the production period. All enter- prises using lovegrass during the April 15-May 15 period were rotated to tobosagrass pastures for this period to protect the lovegrass productivity. Eight steer and six heifer enterprises were considered on tobosagrass. Livestock stocking rates were derived from median forage production and utilization values obtained from relatively intense management of pastures in west Texas by Texas Tech University researchers.

The linear programming model used to maximize net ranch income included the 48 enterprises (Table 1) plus 36 transfer activities. The transfer activities transferred consumed grass from one month to the next. The limiting resources were land area in each of the grasses and labor. Allocation of land was based on daily grass consumption per head for each month for each enterprise. The total amount of grass available in any month was the sum of grass produced and grass transferred into that month, less the senescence and trampling losses.

Table 1. Specification of enterprises evaluated in ranch operation.

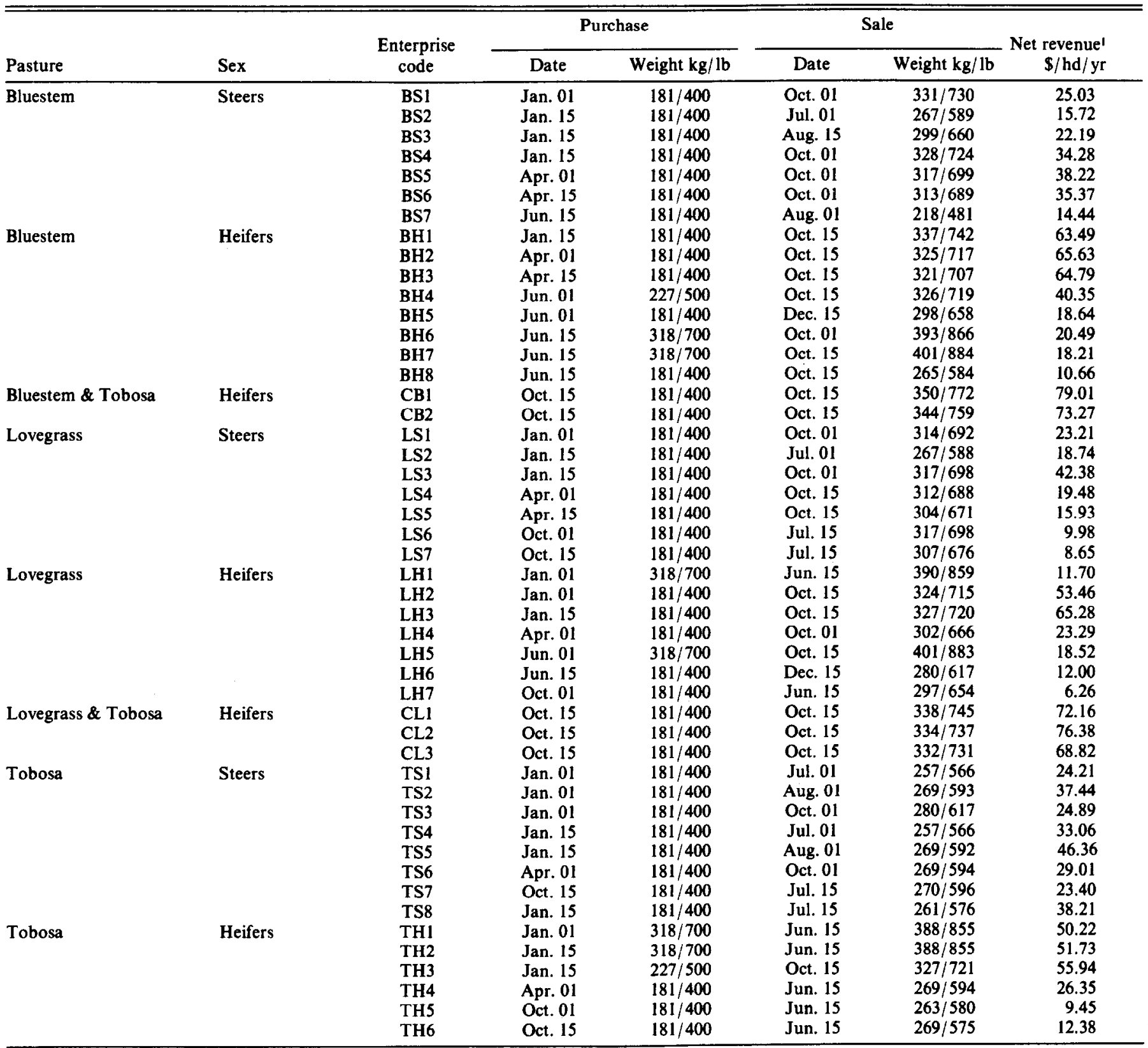


Labor requirements for each enterprise were specified on a per month basis. Estimates of labor required were from Texas Agricultural Extension Service/Texas Agricultural Experiment Station (1984) livestock enterprise budgets for the region. An additional $.04 \mathrm{hr}$ of labor per head was used in the month when animals were purchased to account for vaccination, branding, and associated activities. The months when the cattle were sold, as well as when the cattle were rotated from one site to another, had an additional $.02 \mathrm{hr}$ more labor per head added. Labor available in each month was the number of daylight hours in that month, or the labor of one man working daylight to dusk each day.

Three model solutions were obtained, one each for average, high, and low cattle prices. Average prices were 7-year averages of prices for each weight group for each month (Nance et al. 1985). High and low cattle prices were 1 standard deviation above and below the average, respectively. Because price variability is not constant across months, weight groups, or sex, net returns of the various enterprises did not move proportionately.

\section{Results}

A result common to all solutions was that labor requirements never exceeded the total labor available. However, additional labor was hired for veterinary and processing activities during the months of purchasing and selling.

The optimal solutions are summarized in Table 2 . The average cattle price model yielded a total annual net return over variable costs of $\$ 19,833$ on the 397 ha and net returns to land and management of $\$ 14,549$ after subtracting the $\$ 5,284$ fixed costs of the ranch. The bluestem site's cattle production was limited to 65 head of heifers by the grass produced and transferred into August, all of which was consumed. The value of the dual activity (the activity's shadow price) for the bluestem site was $\$ .0441 / \mathrm{kg}(.02 / \mathrm{lb})$; an additional kilogram of bluestem grass would increase net income by $\$ .0441$. An additional hectare of the bluestem would have increased net ranch returns by $\$ 142$ per year $(\$ .0441 / \mathrm{kg} \times 3,226 \mathrm{~kg}$ grass/ha/yr). The additional hectare would produce net income from almost 2 heifers.

The lovegrass site was limited to 61 heifers by the grass available in March. The value of the dual activity for this site was $\$ .0331 / \mathrm{kg}$ $(\$ .015 / \mathrm{lb})$, indicating that an additional hectare of lovegrass would be worth $\$ 119$ annually. The tobosagrass site was limited to 225 heifers by the grass available in April. The shadow price was $\$ .0441 / \mathrm{kg}(\$ .02 / \mathrm{lb})$ and the value of an additional hectare of tobosagrass was $\$ 35.58(\$ 14.40 / \mathrm{ac})$.

In the average cattle price model, $\$ 70,241$ of annual operating capital (to purchase cattle, feed, supplies, and other operating cost items) was required for the enterprises. The operating capital for the lovegrass enterprise was larger than for bluestem and tobosagrass. The extended duration of grazing on lovegrass required more supplemental feeding, fertilization, and interest cost (Nance et al. 1985).

The optimal solution for the high cattle price model yielded a net return over variable costs of $\$ 22,881$ and a net return to land and management of $\$ 17,597,15$ and $21 \%$ above the average price model solutions, respectively. The solution consisted of 282 steers on bluestem, 61 heifers on lovegrass, and 225 heifers on tobosagrass, and required $\$ 79,083$ of operating capital.

Bluestem use was limited to 282 head by the grass available in July. The value of additional bluestem grass was $\$ .044 / \mathrm{kg}$ or $\$ 142 /$ ha annually. Allocation of the lovegrass and tobosagrass did not vary from the average price model, but their net returns did. The shadow price for lovegrass fell to $\$ .022 / \mathrm{kg}(\$ .01 / \mathrm{lb})$ of grass and $\$ 46 / \mathrm{ha}(\$ 18.72 / \mathrm{ac})$ annually. This happened because increased cattle prices caused per head net revenue to decline on lovegrass and increase on tobosagrass.

With low cattle prices, the optimal solution resulted in net returns over variable costs of $\$ 22,593,14 \%$ over those for the average price model, and net returns to land and management were $19 \%$ greater. These returns were generated with 65 heifers on bluestem, 61 heifers on lovegrass, and 201 steers on tobosagrass and required $\$ 52,135$ of operating capital. Use of the bluestem and lovegrass sites for the low price model did not vary from the average price model, but the value of an additional kilogram (ha) of bluestem increased to $\$ .0441$ ( $\$ 158$ ) annually. The 201 head on tobosagrass was limited by grass available in April. The shadow price of an additional $\mathrm{kg}$ (ha) of tobosagrass was $\$ .0441$ (\$36) annually in the low price model.

The optimal ranch use with average cattle prices is production of heifers on all sites. With high cattle prices, the optimal solution substitutes steers for heifers on the bluestem site. Low cattle prices results in substitution of steers on tobosagrass and the same use of the other sites as with average cattle prices.

Comparison of results with average, high, and low cattle prices shows that income is highly dependent on the buy-sell price differentials, not on absolute price levels. These results also indicate that variation in cattle prices, if predictable, do not lower net returns if the enterprise mix can be varied in response to price changes. Net returns were greater with both high and low cattle prices than with average prices. Increased profits with low cattle prices resulted from a decrease in purchase prices relative to sale prices due to

Table 2. Optimal ranch plans under three cattle price levels.

\begin{tabular}{|c|c|c|c|c|c|c|c|c|c|c|}
\hline \multirow{2}{*}{$\begin{array}{l}\text { Cattle } \\
\text { price } \\
\text { level }\end{array}$} & \multirow[b]{2}{*}{ Pasture } & \multirow[b]{2}{*}{$\begin{array}{l}\text { Number } \\
\text { (head) }\end{array}$} & \multirow[b]{2}{*}{ Sex ${ }^{\prime}$} & \multicolumn{3}{|c|}{ Purchase } & \multicolumn{3}{|c|}{ Sale } & \multirow[b]{2}{*}{ Net revenue $_{\$}^{2}$} \\
\hline & & & & $\begin{array}{l}\text { Weight } \\
\mathrm{kg}(\mathrm{lb})\end{array}$ & $\begin{array}{c}\text { Price } \\
\mathfrak{c} / \mathrm{kg}(\mathfrak{q} / \mathrm{lb})\end{array}$ & Date & $\begin{array}{l}\text { Weight } \\
\mathrm{kg}(\mathrm{lb})\end{array}$ & $\begin{array}{c}\text { Price } \\
\mathfrak{c} / \mathbf{k g}(\mathfrak{c} / \mathbf{l b})\end{array}$ & Date & \\
\hline \multirow[t]{2}{*}{ Average } & $\begin{array}{l}\text { Bluestem } \\
\text { Lovegrass } \\
\text { Tobosa }\end{array}$ & $\begin{array}{r}65 \\
61 \\
225 \\
\end{array}$ & $\begin{array}{l}\mathbf{H} \\
\mathbf{H} \\
\mathbf{H}\end{array}$ & $\begin{array}{l}181(400) \\
181(400) \\
318(700)\end{array}$ & $\begin{array}{l}146.85(66.61) \\
134.15(60.85) \\
131.44(59.62)\end{array}$ & $\begin{array}{l}\text { Apr. 15 } \\
\text { Jan. 15 } \\
\text { Jan. 15 }\end{array}$ & $\begin{array}{l}321(707) \\
327(720) \\
388(855)\end{array}$ & $\begin{array}{l}136.38(61.86) \\
136.38(61.86) \\
142.44(64.61)\end{array}$ & $\begin{array}{l}\text { Oct. } 15 \\
\text { Oct. 15 } \\
\text { Jun. } 15\end{array}$ & $\begin{array}{r}4,212 \\
3,982 \\
11,639 \\
\end{array}$ \\
\hline & Total & 351 & & & & & & & & 19,833 \\
\hline \multirow[t]{2}{*}{ High } & $\begin{array}{l}\text { Bluestem } \\
\text { Lovegrass } \\
\text { Tobosa }\end{array}$ & $\begin{array}{r}282 \\
61 \\
225 \\
\end{array}$ & $\begin{array}{l}\mathbf{S} \\
\mathbf{H} \\
\mathbf{H}\end{array}$ & $\begin{array}{l}181(400) \\
181(400) \\
318(700)\end{array}$ & $\begin{array}{l}189.57(85.99) \\
162.37(73.65) \\
144.18(65.40)\end{array}$ & $\begin{array}{l}\text { Jun. } 15 \\
\text { Jan. } 15 \\
\text { Jan. } 15\end{array}$ & $\begin{array}{l}218(481) \\
327(720) \\
388(855)\end{array}$ & $\begin{array}{l}185.94(84.34) \\
148.81(67.50) \\
157.92(71.63)\end{array}$ & $\begin{array}{l}\text { Aug. } 01 \\
\text { Oct. 15 } \\
\text { Jun. } 15\end{array}$ & $\begin{array}{r}4,289 \\
3,141 \\
15,451 \\
\end{array}$ \\
\hline & Total & 568 & & & & & & & & 22,881 \\
\hline \multirow[t]{2}{*}{ Low } & $\begin{array}{l}\text { Bluestem } \\
\text { Lovegrass } \\
\text { Tobosa }\end{array}$ & $\begin{array}{r}65 \\
61 \\
201 \\
\end{array}$ & $\begin{array}{l}\mathrm{H} \\
\mathrm{H} \\
\mathrm{S}\end{array}$ & $\begin{array}{l}181(400) \\
181(400) \\
181(400)\end{array}$ & $\begin{array}{l}118.08(53.56) \\
105.93(48.05) \\
125.84(57.08)\end{array}$ & $\begin{array}{l}\text { Apr. } 15 \\
\text { Jan. } 15 \\
\text { Jan. } 15\end{array}$ & $\begin{array}{l}321(707) \\
327(720) \\
269(592)\end{array}$ & $\begin{array}{l}123.94(56.22) \\
123.94(56.22) \\
128.57(58.32)\end{array}$ & $\begin{array}{l}\text { Oct. } 15 \\
\text { Oct. } 15 \\
\text { Aug. } 01\end{array}$ & $\begin{array}{r}5,271 \\
5,097 \\
12,225 \\
\end{array}$ \\
\hline & Total & 327 & & & & & & & & 22,593 \\
\hline
\end{tabular}

I $\mathrm{H}=$ Heifers, $\mathrm{S}=$ Steers

${ }_{2}$ Net returns over variable costs. 
larger standard deviations for prices of lighter cattle than for heavier cattle. Furthermore, low cattle prices decreased operating capital requirements. However, if the ranch manager is to benefit from high or low cattle prices, he must have reliable forecasts of the movement of prices and alter his production strategy to exploit it.

The results of management choices of the high, average, of low cattle price strategies with various outcomes-high, average, or low cattle prices-actually occurring are shown in Table 3. If an

Table 3. Net ranch incomes of various cattle price outcomes under various price strategies.

\begin{tabular}{lccc}
\hline \hline & \multicolumn{3}{c}{ Outcomes } \\
\cline { 2 - 4 } Price strategy & High prices & Average prices & Low prices \\
\hline & 17,517 & 14,409 & 11,494 \\
High prices & 16,460 & 14,549 & 12,910 \\
Average prices & 7,421 & 12,228 & 17,309 \\
Low prices & &
\end{tabular}

average cattle price strategy is followed and average cattle prices actually occur, the ranch makes a net income to land and management of $\$ 14,549$. If the average price strategy is followed and low prices result, the net ranch income (return to land and management) is $\$ 12,910$, a reduction of $\$ 1,639$ from the average price outcome and a reduction of $\$ 4,339(\$ 17,309-\$ 12,810)$ from the low price strategy-low price outcome. Table 3 can be used in the above illustrated manner to evaluate potential losses and gains from various strategies. In general, comparison of the potential outcomes identifies the value of reliable cattle price outlook information to ranch managers.

\section{Conclusions}

The use of improved pastures in ranch production systems coupled with unconventional marketing techniques of seasonal buying and selling activities can increase the profitability of stocker cattle operations. Production of heifers is more profitable than production of steers with average market price differences and the production responses used in this study.

The study also indicates that larger ranch profits can be made with both high and low cattle prices than with average cattle prices if (a) price levels are predictable and (b) ranch production is modified to take advantage of the price movements. The analysis included variations in cattle prices, but normal weather was assumed throughout. Therefore, price risk was recognized but production risk was not.

\section{Literature Cited}

Angirasa, A.K., R. Shumway, T.C. Nelsen, and T.C. Cartwright. 1981. Integration, risk, and supply response: a simulation and linear programming analysis of an east Texas cow-calf producer. So. J. Agr. Econ. 3:89-97.

Bentley, E., and C.R. Shumway. 1981. Adaptive planning over the cattle cycle. So. J. Agr. Econ. 13:139-148.

Kennedy, J.0.S. 1972. A model for determining optimal marketing and feeding policies for beef cattle. Amer. J. Agr. Econ. 23:147-159.

Kessler, F.B., L.C. Aicher, and F.E. Meenen. 1951. Grass utilization and pasture management investigations for 1946-50. Kansas Agr. Exp. Sta.. Circ. 276.

Lance, C.G., G.V. Calvert, and W.A. Griffey. 1974. Alternative cow-calf and stocker production systems in the Georgia piedmont area. J. Range Manage. 27:344-346.

Leistritz, B., and N.J. Qualey. 1975. Economics of ranch management alternatives in southwestern North Dakota. J. Range Manage. 28:349-352.

Morrison, F.B. 1947. Feeds and feeding-a handbook for the student and stockman. The Morrison Publishing Co.

Nance, J.D., B.E. Dahl, and D.E. Ethridge. 1985. Stocker cattle costs and returns for selected purchase and sale dates on different forage pastures, southern plains. College of Agr. Sci., Texas Tech Univ., Pub. No. T-1-231, December.

Snapp, R.R. 1949 (3rd ed.). Beef cattle-their feeding and management in the corn belt states. New York: John Wiley and Sons, Inc.

Texas Agricultural Extension Service and Texas Agricultural Experiment Station. 1984. 1985 Texas crop and livestock budgets. Texas High Plains Region III, November.

Texas Crop and Livestock Reporting Service. 1984. Texas agricultural cash receipts, prices received and paid by farmers, 1983. Texas Department of Agriculture, Marketing Division, and Stat. Reporting Serv., U.S.D.A., Government Printing Office, Washington, D.C.

U.S. Dept. of Agr. 1984. Agricultural statistics, 1983. Stat. Reporting Serv., Government Printing Office, Washington, D.C.

Woodworth, B.M. 1973. Optimizing the calf mix on range lands with linear programming. J. Range Manage. 26:175-178.

\section{JRM 35-year Index Now Available}

The index to volumes 1 through 35, 1948 to 1982, is now available. Edited by Elbert $H$. Reid, the publication contains a subject and author index with keywords and taxons followed by a chronological list of all articles printed in the journal from 1948 to 1982 . Using the two lists enables the reader to locate the subject of interest and identify the articles without going to the magazine itself.

The Index is 100 pages $81 / 2$ by 11 and is perfect bound and sewed. It can be purchased postpaid for $\$ 10.00$ (US) from the Society for Range Management, 1839 York Street, Denver, Colorado 80206. 